\title{
THE EFFECT OF SA 97, PERPHENAZINE, AND HYDROXYZINE ON EPINEPHRINE-INDUCED CARDIAC ARRHYTHMIAS DURING METHOXYFLURANE ANAESTHESIA IN DOGS ${ }^{*}$
}

\author{
Allen B. Dobkin, M.D., and Jacob S. Israel, M.D.
}

Methoxyflurane is a fluorinated ether which is now under laboratory and clinical investigation. ${ }^{1,2,3}$. Although arrhythmias are not prominent during its use clinically it was shown that it may be dangerous to use catecholamines along with it.4.

This report deals with the effect of SA 97, perphenazine (1rilafon ${ }^{\circledR}$ ), and hydroxyzine (Atarax ${ }^{\circledR}$, Vistari ${ }^{\circledR}$ ) on epinephrine-induced cardrac arrhythmias during methoxyflurane anaesthesia in dogs.

SA 97 is N-P-chloro-benzylhydryl-N'-methyl homopiperazine dihydrochloride. It has been offered by Abbott Laboratories for clinical study because it has some useful pharmacological properties. Chemically it is closely related to chlorcyclizine hydrochloride (Diparalene ${ }^{\circledR}$ ), which is an antihistaminic with potent hypnotic properties, and to cyclizine hydrochloride (Marezine ${ }^{\circledR}$ ), which is used mainly for prevention and treatment of nausea and vomiting. SA 97 has a high degree of antiserotonin and antihistaminic activity. It has an antiacetylcholine effect that is mild. It is a coronary dilator, bronchodilator, and has an antifibrillatory effect. The hypnotic effect it produces prolongs thiopental anaesthesia slightly. Clinical trials of this compound have been directed mainly to determining its usefulness in the treatment of allergies. ${ }^{5,6}$

The antifibrillatory effects of perphenazine and hydroxyzine have been studied before, and were used for comparison with SA 97 in these experiments. ${ }^{7,8,9,10}$

\section{MEthod}

Forty-one acute experiments were performed on 11 mongrel dogs. They weighed between 9.0 and $21.5 \mathrm{~kg}$. (mean $15.6 \mathrm{~kg}$.). In the first experiments the dogs were not premedicated. In three subsequent experiments the surviving dogs were premedicated intravenously 30 minutes before the start of anaesthesia with $1 \mathrm{mg}$. $/ \mathrm{kg}$. of SA $97,0.25 \mathrm{mg}$. $/ \mathrm{kg}$. of perphenazine, and $1 \mathrm{mg} . / \mathrm{kg}$. of hydroxyzine respectively. The dose selected for these drugs in each experiment was one that would not be expected to cause appreciable hypotension in the dog.

In preparation for the experiment, each dog was lightly anaesthetized with a sleep dose of thiopental (75-250 mg.), followed by 10 to $20 \mathrm{mg}$. of succinylcholine, if needed, to facilitate endotracheal intubation. A cuffed endotracheal tube was placed in the trachea immediately after induction of anaesthesia. The dog's breathing was then augmented with a Takaoka respirator in order to be sure that pulmonary ventilation would be adequate and that there would not

${ }^{\circ}$ From the Department of Anesthesiology, Upstate Medical Center, Syracuse, New . York.

Can. Anaes. Soc. J., vol. 9, no. 1, January, I962 
be any disturbance to cardiovascular homeostatis other than that due possibly to the methoxyflurane or the epinephrine challenge. ${ }^{11,12}$ Depending on the size of the dog, the minute volume of ventilation was set at 4 to 8 litres per minute. Normal saline infusion was started at the time of thiopental injection to maintain hydration and to keep a vein open. Methoxyflurane was delivered from a calibrated constant-temperature vaporizer (Pentec ${ }^{\circledR}$ ), and was vaporized by a constant flow of oxygen through the vaporizer.

The electrocardiogram (lead 2) was recorded on each dog with a standard clinical recorder. A control tracing was taken immediately after endotracheal intubation while the dog was ventilated with 100 per cent oxygen only. One per cent methoxyflurane wás then started. This concentration was selected because in previous work it was found to give a stable level of anaesthesia without serious cardiovascular depression. ${ }^{3}$ Electrocardiogram tracings were taken every 5 minutes until 25 minutes after the start of anaesthesia. Then a continuous recording was taken and the epinephrine challenge given. The recording was continued until it returned to a configuration which was similar to that before the injection, or until death occurred.

The concentration, dose, and rate of injection of epinephrine was $0.02 \mathrm{mg}$. $\mathrm{ml} . / \mathrm{kg}$. body weight per second, as used in previous similar studies. ${ }^{7,8,13}$

\section{Results}

The average heart rate of the unpremedicated dogs was $149 \pm 47$ per minute following endotracheal intubation, but before anaesthesia was begun with methoxyllurane. The average heart rate in the dogs treated with SA 97 was $158 \pm 27$ per minute, while that for the dogs treated with perphenazine and hydroxyzine was $121 \pm 24$ and $122 \pm 33$ respectively.

The time of onset of cardiac arrhythmias after the start of the epinephrine injection was 12.1 seconds for the unpremedicated dogs and 13.1, 12.8, and 13.4 seconds for the dogs pretreated with SA 97, perphenazine, and hydroxyzine respectively. The type and incidence of cardiac arrhythmias that occurred are summarized in Tables I and II.

TABLE I

InCidence of Arrhythmias due to Epinephrine Challenge during Methoxyflurane AnaEsthesia

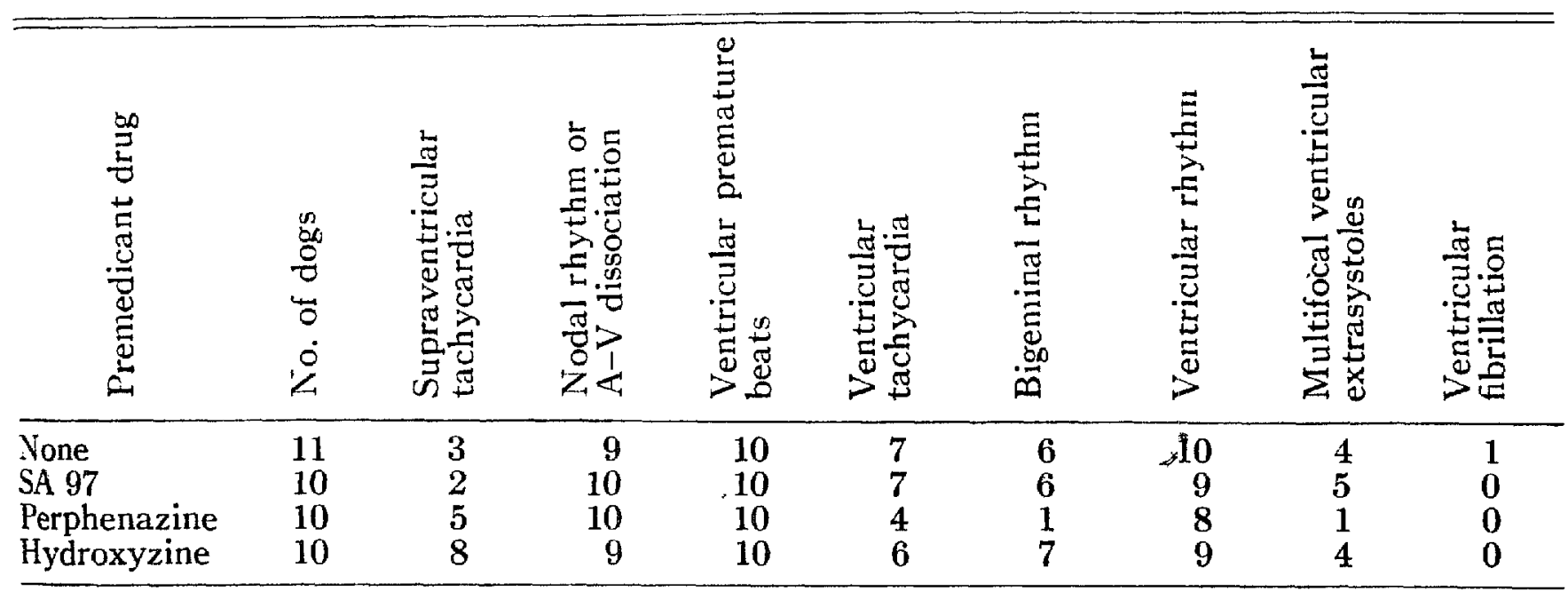


TABLE II

Mean Duration of Arrhythmias due to Epinephrine Challienge DURing MethoXYiflurane ANaEsthesia.

\begin{tabular}{clccc}
\hline No. of dogs & Premedicant drugs & $\begin{array}{c}\text { Onset of arrhythmia } \\
\text { (seconds after } \\
\text { epinephrine) }\end{array}$ & $\begin{array}{c}\text { Duration of } \\
\text { ventric. } \\
\text { arrhythmia, seconds }\end{array}$ & $\begin{array}{c}\text { Total duration } \\
\text { of arrhythmias, } \\
\text { seconds }\end{array}$ \\
\hline 11 & None & 12.1 & 57 & $215^{*}$ \\
10 & $\begin{array}{l}\text { SA 97, } 1 \mathrm{mg} . / \mathrm{kg} . \\
\text { Perphenazine, } \\
0.25 \mathrm{mg} . / \mathrm{kg} .\end{array}$ & 13.1 & 75 & 188 \\
10 & $\begin{array}{c}\text { Hydroxyzine, } \\
\text { 1 mg./kg. }\end{array}$ & 13.4 & 15 & $218(200 \dagger)$ \\
\hline
\end{tabular}

*Excluding one dog that developed ventricular fibrillation.

†Excluding one dog that had prolonged arrhythmia.

The duration of cardiac arrhythmias was 215 seconds in the dogs and 188, 137, and 218 seconds in the dogs pretreated with SA 97, perphenazine, and hydroxyzine respectively. One of the dogs pretreated with hydroxyzine had a prolonged arrhythmia which weighted the results. Excluding this experiment, the average duration of the arrhythmias in the hydroxyzine-pretreated dogs was 200 seconds.

\section{Discussion}

Cardiac arrhythmias of a serious nature may occur during general anaesthesia with all of the commonly used halogenated anaesthetics. ${ }^{14}$ These may become lethal if inadequate pulmonary ventilation is allowed to persist $t^{15}$ or if catecholamines are administered at the same time. ${ }^{16,1 T}$

Slowing of the heart rate appears to be a charcteristic effect of methoxyllurane, as is seen with most of the halogenated anaesthetics. ${ }^{3}$

The electrocardiogram tracings obtained with methoxyflurane were compared with recordings obtained during similar experiments with halothane, halothaneether azeotrope, cyclopropane, chloroform, and trichlorethylene and it was observed that the arrhythmias were similar. The severity of the arrythmias and the likelihood of a lethal effect with methoxyflurane was of the same order as that seen with the halothane-ether azeotrope, and much less than that seen with trichlorethylene, cyclopropáne, and halothane. ${ }^{7,8,18}$

Several of the phenothiazine derivatives have been shown to reduce the incidence of cardiac arrhythmias caused by the combination of halogenated anaesthetics and catecholamines. $\eta_{1}, 8,13,10,20$ In this study, perphenazine pretreatment appeared to be effective. The duration of arrythmias was shorter after perphenazine pretreatment than after pretreatment with SA 97 or hydroxyzine and none of these animals developed a "prefibrillation" arrhythmia.

SA 97 along with other antihistaminics is known to be effective in reducing ventricular arrhythmias. ${ }^{21}$ This action was seen after the epinephrine challenge in the experiments reported here but SA 97 was less effective than perphenazine. Since one animal developed a prefibrillation pattern on the ECG the protective effect cannot be considered reliable. 
Hydroxyzine gave some protection against the severest ventricular arrhythmias, although the overall duration of the abnormal rhythms was not affected appreciably. Atrial tachycardia was observed more often in the hydroxyzineprotected animals than after any of the other tests, including the non-premedicated animals. Another interesting observation was that the dogs that received hydroxyzine had an abrupt change from ventricular arhythmia to a regular sinus tachycardia, whereas the changes to normal were gradual in the other experiments. In any case hydroxyzine was not as effective as perphenazine in preventing epinephrine-induced arrhythmias.

\section{Summary ANd Conclusions}

Forty-one acute experiments were done on 11 mongrel dogs after 25 minutes of 1 per cent methoxyflurane-oxygen anaesthesia to determine the severity of cardiac arrhythmias produced by an epinephrine challenge and to evaluate the efficacy of SA 97 (an antihistaminic) as a protectant. Perphenazine and hydroxyzine were also used as a cornparison with SA 97 .'Pulmonary ventilation was augmented during anaesthesia to eliminate hypoxia and hypercarbia during the experiments. The doses selected for each agent were such that severe hypotension would not be expected to occur prior to the epinephrine challenge.

The arrhythmias provoked by an epinephrine challenge during methoxyflurane anaesthesia were less severe than those seen in similar experiments with trichlorethylene, cyclopropane, and halothane, but were similar to those during anaesthesia with halothane-ether azeotrope and light chloroform.

Perphenazine in a dose of $0.25 \mathrm{mg}$. $/ \mathrm{kg}$. was more effective than hydroxyzine $(1 \mathrm{mg} . / \mathrm{kg}$.$) and SA 97$ ( $1 \mathrm{mg} . / \mathrm{kg}$.) in reducing cardiac arrhythmias produced by an epinephrine challenge. However, none of the drugs completely eliminated serious ventricular arrhythmias. Therefore, epinephrine should not be used during anaesthesia with methoxyflurane, unless a small amount is injected subcutaneously in a very dilute solution (less than 1:200,000).

\section{RÉSUMÉ}

Après 25 minutes d'anesthésie avec 1 pour cent de méthoxyflurane et oxygène, chez 11 chiens mongrel, nous avons pratiqué 41 expériences pour déterminer la fréquence des arythmies cardiaques produites par l'administration d'épinéphrine et, en même temps, le degré de protection procurée par le SA 97 (un antihistaminique). Nous avons également employé la perphénazine et Phydroxyzine pour en comparer les effets avec ceux du SA 97. Au cours des anaesthésies, nous avons augmenté les échanges respiratoires pour éliminer toute hypoxie ou toute hypercarbie au cours des expériences. Pour chacun de ces agents, nous avions déterminé une dose telle qu'il n'y avait pas lieu de craindre lappparition d'une hypotension marquée avant l'injection d'épinéphrine.

Les arythmies provoquées par l'injection d'épinéphrine durant l'anesthésie au méthoxyflurane ont été moins marquées que celles observées au cours d'expériences semblables avec le trichloréthylène, le cyclopropane et l'halothane, 
mais elles ressemblaient à celles que nous avons observées au cours de l'anesthésie halothane-éther azéotropique et l'anesthésie légère au chloroforme.

La perphénazine à raison de $0.25 \mathrm{mg} . / \mathrm{kg}$. s'est avérée plus efficace que l'hydroxyzine ( $1 \mathrm{mg} . / \mathrm{kg}$.) et le SA 97 (1 mg./kg.) pour diminuer les arythmies cardiaques occasionnées par l'injection d'épinéphrine.

Toutefois, aucun de ces médicaments n'a réussi à faire disparaître complètement l'arythmie ventriculaire importante. En conséquence, au cours de l'anesthésie au méthoxyflurane, il serait déconseillé de faire usage d'épinéphrine chez le malade, à moins qu'il ne s'agisse que d'une petite quantité administrée en injection sous-cutanée et en solution très diluée (moins de 1:200,000).

\section{ACKNOWLEDGMENTS}

This work was supported by a grant from Doctor Norman Wher of Abbott Laboratories, who also provided a generous supply of methoxyflurane (Penthrane) and SA 97. The Pentec vaporizer was kindly supplied by Cyprane Ltd., Yorkshire, England, by arrangement with Mr. Fraser Sweatman. The calibration of this instrument was checked by Mr. W. Edmonson of Cyprane Ltd.

\section{REFERENCES}

1. Artusio, J. F.; Van Poznak, A.; Hunt, R. E.; Trers, F. M.; \& Alexander, M. Clinical Evaluation of Methoxyflurane in Man. Anesthesiology 21: 512 (1960).

2. Wasmuth, C. E. et al. Methoxyflurane-New Anesthetic Agent-Clinical Evaluation Based on 206 cases. Cleveland Clin. Quart. 27: 174 (1960).

3. Dobkin, A. B., \& FEDORuK, S. Comparison of the Cardiovascular Respiratory and Metabolic Effects of Methoxyflurane and Halothane in Dogs. Anesthesiology 22: 355 (1961).

4. Bamforth, B. J.; Siebecker, K. L.; Kraemer, R.; \& ORth, O. S. Effect of Epinephrine on the Dog Heart During Methoxyflurane Anesthesia. Anesthesiology 22: 169 (1961).

5. WheEler, N. Abbott Laboratories. Personal communication.

6. DriLl, V. A., Pharmacology in Medicine. 2nd. ed. McGraw-Hill (1958). Pp. 626-32.

7. Doвkin, A. B., \& Purkin, N. The Effect of Perphenazine on Epinephrine Induced Cardiac Arrhythmias in Dogs. I. Anaesthesia with Fluothane and the Fluothane-Ether Azeotrope. Canad. Anaesth. Soc. J. 6: 243 (1959).

8. Dobrin, A. B.; Donaldson, H.; \& Purkin, N. The Effect of Perphenazine on Epinephrine-Induced Cardiac Arrhythmias in Dogs. 2. Anaesthesia with Cyclopropane Chloroform and Trichlorethylene. Canad. Anaesth. Soc. J. 6: 251 (1959).

9. Hutcheon, D. E.; Scriabine, A.; \& MorRis, D. L. Cardiovascular Action of Hydroxyzine. J. Pharmacol. \& Exper. Therap. 118: 451 (1956).

10. Burrell, Z. L.; Gittinger, W. C.; \& Martinez, A. Treatment of Cardiac Arrhythmias with Hydroxyzine. Am. J. Cardiol. 1: 624 (1958).

11. Virtue, R. W.; Caronna, L. J.; \& Takaoka, K. The Respiratory Pattern and Cardiac Output. Brit. J. Anaesth. 33: 77 (1961).

12. Dobkin, A. B. The Takaoka Respirator for Automatic Ventilation of the Lungs. Canad. Anaesth. Soc. J. 8: 556 (1961).

13. Dobkin, A. B.; Gllbert, R. G. B.; \& Melville, K. I. Chlorpromazine: Reviéw and Investigation as a Premedicant in Anesthesia. Anesthesiology 17: 135 (1956):

14. Donkin, A. B. The Effect of Anaesthetic Agents on the Cardiovascular System: A Review. Canad. Anaesth. Soc. J. 7: 317 (1960).

15. Mrller, F. A.; Brown, E. B.; Buckley, J.; Van Bergen, F. H.; \& Varico, R. L. Respiratory Acidosis: Its Relationship to Cardiac Function and Other Physiologic Mechanisms. Surgery $32: 171$ (1952). 
DOBKIN \& ISRAEL: EPINEPHRINE DURING METHOXYFLURANE ANAESTHESLA

16. Orth, O. S.; Leigh, M. D.; Mellish, C. H.; \& Stutzman, J. W. Action of Sympathomimetic Amines in Cyclopropane and Chloroform Anaesthesia. J. Pharmacol. \& Exper. Therap. 67: 1 (1939).

17. MEEK, W. J. Some Cardiac Effects of Inhalent Anesthetics and the Sympathomimetic Amines. Harvey Lect. 36: 188 (1941).

18. Dobkin, A. B.; Drummond, K.; \& Purkin, N. Anaesthesia with the Azeotropic Mixture of Halothane and Diethyl Ether. Brit. J. Anaesth. $31: 53$ (1959).

19. Dobkin, A. B. Efficacy of Ataractic Drugs in Clinical Anaesthesia. Canad. Anaesth. Soc. J. 5: 176 (1958).

20. Arora, R. B. Antiarrhythmics: Quinidine-like Activity of Some Ataractic Agents. J. Pharmacol. \& Exper. Therap. 124: 53 (1958).

21. Levrtan, B. A., \& Scotr, J. H. Inhibition of Chloroform-Adrenalin Fibrillation by Antihistamines. Canad. M.A.J. 61 : 303 (1949). 